\title{
A sensitive method for analyzing fluconazole in extremely small volumes of neonatal serum
}

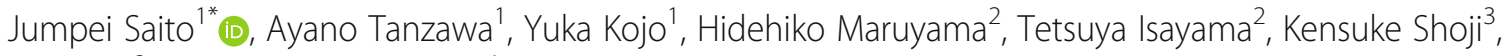
Yushi Ito $^{2}$ and Akimasa Yamatani ${ }^{1}$

\begin{abstract}
Background: The need for a large volume of serum sample significantly reduces the feasibility of neonatal pharmacokinetic studies in daily practice, which must often rely on scavenged or opportunistic sampling. This problem is most apparent in preterm newborns, where ethical and practical considerations prohibit the collection of large sample volumes. Most of the fluconazole analysis assays published thus far required a minimum serum sample of 50 to $100 \mu \mathrm{L}$ for a single assay. The purpose of the present study was to develop and validate a sensitive method requiring a smaller sample volume $(10 \mu \mathrm{L})$ to satisfy clinically relevant research requirements.

Methods: Following simple protein precipitation and centrifugation, the filtrated supernatant was injected into a liquid chromatography system and separated with a C18 reverse-phase column. Fluconazole and the internal standard (IS, fluconazole-d4) were detected and quantified using tandem mass spectrometry. The method was validated with reference to the Food and Drug Administration's Guidance for Industry. Accuracy and precision were evaluated at six quality control concentration levels (ranging from 0.01 to $100 \mu \mathrm{g} / \mathrm{mL}$ ).

Results: Investigated calibration curves were linear in the $0.01-100 \mu \mathrm{g} / \mathrm{mL}$ range. Intra- and inter-day accuracy ( -7.7 to $7.4 \%$ ) and precision (0.3 to 6.0\%) were below $15 \%$. The calculated limit of detection and the lower limit of quantification (LLOQ) was $0.0019 \mu \mathrm{g} / \mathrm{mL}$ and $0.0031 \mu \mathrm{g} / \mathrm{mL}$, respectively. Fluconazole in the prepared samples was stable for at least 4 months at $-20^{\circ} \mathrm{C}$ and $-80^{\circ} \mathrm{C}$. This method was applied to analyze 234 serum samples from ten neonates who received fosfluconazole, a water-soluble phosphate prodrug of fluconazole which converts to fluconazole in the body, as part of a pharmacokinetic study using daily scavenged laboratory samples. The median (range) concentration up to $72 \mathrm{~h}$ after fosfluconazole administration was $2.9(0.02$ to $26.8 \mu \mathrm{g} / \mathrm{mL}) \mu \mathrm{g} / \mathrm{mL}$, which was within the range of the calibration curve.

Conclusion: Fluconazole was able to be detected in an extremely small volume $(10 \mu \mathrm{L})$ of serum from neonates receiving fosfluconazole. The method presented here can be used to quantify fluconazole concentrations for pharmacokinetic studies of the neonatal population by using scavenged samples.
\end{abstract}

Keywords: Fosfluconazole, Fluconazole, Liquid chromatography-tandem mass spectrometry, Neonate, Serum sample volume

\footnotetext{
* Correspondence: saito-jn@ncchd.go.jp

'Department of Pharmacy, National Center for Child Health and Development, 157-8535, 2-10-1 Okura, Setagaya-ku, Tokyo, Japan

Full list of author information is available at the end of the article
}

(c) The Author(s). 2020 Open Access This article is licensed under a Creative Commons Attribution 4.0 International License, which permits use, sharing, adaptation, distribution and reproduction in any medium or format, as long as you give appropriate credit to the original author(s) and the source, provide a link to the Creative Commons licence, and indicate if changes were made. The images or other third party material in this article are included in the article's Creative Commons licence, unless indicated otherwise in a credit line to the material. If material is not included in the article's Creative Commons licence and your intended use is not permitted by statutory regulation or exceeds the permitted use, you will need to obtain permission directly from the copyright holder. To view a copy of this licence, visit http://creativecommons.org/licenses/by/4.0/. The Creative Commons Public Domain Dedication waiver (http://creativecommons.org/publicdomain/zero/1.0/) applies to the data made available in this article, unless otherwise stated in a credit line to the data. 


\section{Background}

The incidence of invasive fungal infection ranges from 2 to $16 \%$ in neonates with very low birth weight (VLBW < $1500 \mathrm{~g})[1,2]$, and a higher incidence was found in infants with lower birth weight and in premature neonates [3]. In previous studies, the mortality rate following Candida infection was found to range from 30 to $40 \%$, and neurodevelopmental impairment was common among survivors $[4,5]$. Although the universal use of antifungal prophylaxis is still controversial, prophylactic fluconazole is generally recommended for extremely low birth weight (ELBW $<1000 \mathrm{~g}$ ) neonates, especially in neonatal intensive care units (NICU) with a prevalence of Candida spp. infection higher than 5\% [6]. At our center, fosfluconazole, a water-soluble phosphate prodrug of fluconazole which is more highly soluble than fluconazole, is frequently used for antifungal prophylaxis in preterm neonates to minimize the infusion volume [7]. Although the pharmacokinetics of fluconazole after fosfluconazole treatment in adults is well documented, an appropriate, validated dosing regimen for neonates with VLBW and ELBW does not yet exist, and further clinical pharmacokinetic (PK) research is required. However, to be able detect fluconazole at a quantification limit of $0.5 \mu \mathrm{g} / \mathrm{mL}$ for PK studies [8], a 100 to $200 \mu \mathrm{L}$ whole blood sample (about 50 to $100 \mu \mathrm{L}$ of plasma or serum) is required for a single assay (Table 1) [9-24]. To perform replicate analysis to reduce the preparation bias, two- to threefold this quantity is needed [25]. However, in preterm neonates, blood sampling is limited due to ethical and practical considerations. Although an opportunistic strategy using scavenged samples combined with population PK modeling has been proposed as an alternative to conventional methods of performing PK studies in neonates, the need for a large sample volume significantly limits its feasibility.

\section{Methods}

\section{Chemicals and standards}

Fluconazole $(>99.0 \%)$ and its internal standard (IS, fluconazole-d4 stable isotope $(>99.0 \%)$ ) were purchased from Toronto Research Chemical (North York, Ontario, Canada). Mass spectrometry-grade methanol, acetonitrile, formic acid, and ammonium formate were obtained from Sigma-Aldrich (St. Louis, MO, USA). Ultrapure water was obtained using a Milli-Q system (Millipore, Bedford, USA). Stock solutions of fluconazole (2 $\mathrm{mg} / \mathrm{mL})$ and IS $(1 \mathrm{mg} / \mathrm{mL})$ were prepared in acetonitrile and stored at $-80^{\circ} \mathrm{C}$ in a freezer.

\section{Liquid chromatography-tandem mass spectrometry conditions}

The liquid chromatography-tandem mass spectrometry (LC-MS/MS) system used in the present study consisted of the TSQ Vantage triple stage quadrupole mass spectrometer connected to Dionex UltiMate 3000 (Thermo Fisher Scientific K.K., Tokyo, Japan). The LC system consisted of an Ultimate 2000 SRD degasser, Ultimate 3000 RS binary solvent pump system, column oven, and Ultimate 3000 RS autosampler. Identification of the

Table 1 Existing methods for fluconazole quantification in human whole blood, plasma, and serum

\begin{tabular}{|c|c|c|c|c|c|c|}
\hline & Method & Sample type & Sample volume $(\mu \mathrm{L})$ & Sample preparation & LOQ $(\mu \mathrm{g} / \mathrm{mL})$ & Reference No. \\
\hline 1 & LC-MS & Serum & 25 & No pretreatment & 0.1 & [9] \\
\hline 2 & LC-MS & Plasma & 50 & LLE & 0.0005 & [10] \\
\hline 3 & LC-MS & Plasma & 50 & PP & 0.03 & [11] \\
\hline 4 & LC-UV & Serum & 50 & SPE & 0.1 & [12] \\
\hline 5 & LC-UV & Plasma & 50 & SPE & 0.2 & [13] \\
\hline 6 & LC-MS & Plasma & 70 & PP & 0.01 & [14] \\
\hline 7 & LC-MS & Serum & 75 & PP & 0.06 & [15] \\
\hline 8 & LC-MS & Plasma & 100 & PP & 0.1 & [16] \\
\hline 9 & LC-MS & Plasma & 100 & PP & 0.1 & [17] \\
\hline 10 & LC-MS & Plasma & 100 & PP & 0.1 & [18] \\
\hline 11 & LC-MS & Serum & 100 & PP & 0.2 & [19] \\
\hline 12 & LC-MS & Plasma & 100 & DBS & 0.5 & [20] \\
\hline 13 & LC-MS & Serum & 100 & PP & 0.5 & [21] \\
\hline 14 & LC-UV & Plasma & 300 & SPE & 0.05 & [22] \\
\hline 15 & LC-UV & Whole blood & 300 & SPE & 0.5 & [23] \\
\hline 16 & LC-UV & Plasma & 500 & LLE & 0.4 & [24] \\
\hline
\end{tabular}

The reported fluconazole determination method has a limit of quantification equal to or greater than $0.5 \mu \mathrm{g} / \mathrm{mL}$ Abbreviations: $L C$ liquid chromatography, MS mass-spectrometry, UV ultraviolet, PP protein precipitation, LLE liquid-liquid extraction, SPE solid phase extraction, DBS dried blood spot 
compound was based on the relative retention time and product ion ratio. Chromatographic separation of fluconazole and IS was performed over a total run time of $5 \mathrm{~min}$ on the Imtakt UK-C18 column $(3 \mu \mathrm{m}, 3.0$ $\mathrm{mm} \times 50 \mathrm{~mm}$, Imtakt, Kyoto, Japan) and was maintained at $37^{\circ} \mathrm{C}$. The mobile phases consisted of $0.1 \%$ formic acid and $10 \mathrm{mM}$ ammonium formate in water ( $\mathrm{pH}$ 3.0) (mobile phase A) and $0.1 \%$ formic acid and $10 \mathrm{mM}$ ammonium formate in methanol (mobile phase B). A linear gradient was run at a flow rate of $0.4 \mathrm{~mL} / \mathrm{min}$. Mobile phase $\mathrm{B}$ was run at $5 \%$ over $0-1$ min, 5-95\% over $1-2 \mathrm{~min}$, maintained at $95 \%$ for 1 min (3-4 min), then returned to 5\% (initial condition). The samples were kept at $10^{\circ} \mathrm{C}$ in the auto-sampler, and a $10 \mu \mathrm{L}$ volume was injected into the LC system.

The LC-MS/MS conditions were as follows: Electrospray ionization analysis was conducted in the positive mode; the spray voltage was $3500 \mathrm{~V}$; the vaporizer temperature was $400^{\circ} \mathrm{C}$; the sheath gas and auxiliary gas (both nitrogen) pressure was 60 and 10 arbitrary units, respectively; the in-source collision-induced dissociation was set at $4 \mathrm{~V}$; and the capillary temperature was $350{ }^{\circ} \mathrm{C}$. The collision energy and S-lens voltage were set at $15 \mathrm{eV}$ and $70 \mathrm{~V}$ for fluconazole and $13 \mathrm{eV}$ and $74 \mathrm{~V}$ for IS. The collision gas (argon) pressure at the second quadrupole was 1.5 mTorr. Mass spectra were acquired by selected reaction monitoring. The optimal MS/MS transitions were determined separately by direct infusion of each compound solution at a $10 \mu \mathrm{L} / \mathrm{min}$ flow rate into the MS/MS detector at a $10 \mu \mathrm{g} / \mathrm{mL}$ concentration in mobilephase mixing. The selected $\mathrm{m} / \mathrm{z}$ transitions were $307.1>$ 238.1 for fluconazole and $311.1>242.2$ for IS. Chromatographic data acquisition, peak integration, and quantification were performed using the QUAL and QUAN browsers of the Xcalibur software package (Thermo Fischer Scientific K.K., Tokyo, Japan).

\section{Sample preparation}

For sample preparation, $4 \mu \mathrm{L}$ IS $(25 \mu \mathrm{g} / \mathrm{mL}$ in acetonitrile) and $40 \mu \mathrm{L}$ acetonitrile were added to each $10 \mu \mathrm{L}$ serum sample. Subsequently, the samples were vortexed for $30 \mathrm{~s}$ before being centrifuged $(11,180 \times g)$ at $4{ }^{\circ} \mathrm{C}$ for $10 \mathrm{~min}$. Approximately 35 to $40 \mu \mathrm{L}$ of supernatant was transferred to a $0.2 \mu \mathrm{m}$ filtration tube (Nacalai Tesque, Inc., Kyoto, Japan). Samples obtained by filtration were centrifuged $(1000 \times g)$ at $4{ }^{\circ} \mathrm{C}$ for $1 \mathrm{~min}$ before being transferred into auto-sampler vials.

\section{Calibration standards and quality control}

A calibration standard curve for fluconazole was constructed by preparing six blank serum samples ranging in quantity from 0.01 to $100 \mu \mathrm{g} / \mathrm{mL}(0.01,0.1,1,10,50$ and $100 \mu \mathrm{g} / \mathrm{mL}$ ). These samples were also used for quality control $(\mathrm{QC})$ and were stored at $-80^{\circ} \mathrm{C}$.

\section{Limit of detection (LOD) and lower limit of quantification} (LLOQ)

The limit of detection (LOD) was defined as the lowest concentration at which the analyte was able to be detected reliably, and the lower limit of quantification (LLOQ) was defined as the lowest concentration at which the analyte was able to be quantified, according to the Food and Drug Administration [26]. The LOD was determined on the basis of the standard deviation of the response (Sy) of the curve and the slope of the calibration curve (S) [27]. The LOD was approximately 3.29 $(\mathrm{Sy} / \mathrm{S})$. The standard deviation of the response was determined on the basis of the standard deviation of the $y$ intercept of the regression line. For the LLOQ, the calculation method was again based on the Sy and S according to the formula: $\mathrm{LLOQ}=10(\mathrm{Sy} / \mathrm{S})$.

\section{Recovery, precision, and accuracy}

Precipitation recovery was determined by calculating the ratio (\%) of the area response of the samples (normalized by the internal standard) after precipitation with the pure standard solutions at QC concentrations. Accuracy was determined by replicate analyses of the six concentrations $(0.01,0.1,1,10,50$, and $100 \mu \mathrm{g} / \mathrm{mL})$. The deviation of the mean from the true value was expected to be within $15 \%$ of the actual value [26]. The precision of the assay was measured as the percent coefficient of variation for the eight concentrations during the course of validation. Intraday assay variations were determined by analyzing six replicate samples at each concentration on a single day. Interday assay variations were determined by analyzing four replicate samples at each concentration on four separate days.

\section{Matrix and carry-over effects}

Matrix effect was checked with six different lots of serum. Three replicate samples each of the two concentration samples $(0.1$ and $100 \mu \mathrm{g} / \mathrm{mL})$ were prepared from different lots of plasma (36 QC samples in total). Potential sample carry-over was assessed by analyzing serum samples spiked with concentrations of fluconazole at the highest QC sample $(100 \mu \mathrm{g} / \mathrm{mL})$ followed by blank samples. The carry-over test was repeated six times.

\section{Stability}

A series of serum samples spiked with fluconazole at concentrations of $0.01,0.1,1,10$ and $100 \mu \mathrm{g} / \mathrm{mL}$ were prepared, and the final samples were stored at $-20{ }^{\circ} \mathrm{C}$ and $-80^{\circ} \mathrm{C}$ for 4 months. For each concentration, three replicate samples were analyzed. The stability of fluconazole in five QC samples was studied under the autosampler condition of $4{ }^{\circ} \mathrm{C}$ for $48 \mathrm{~h}$ by comparing the peak areas obtained from the stored samples and freshly prepared samples. For freeze-thaw stability test, fluconazole 
concentrations in five QC samples after six freeze-thaw cycles were evaluated. The samples were considered stable if the difference in peak area between the stored and freshly prepared samples was $\leq 15 \%$.

\section{Application}

This method was developed to enable fluconazole PK studies in preterm neonates and was approved by the ethical board of the National Center for Child Health and Development. The following were the inclusion criteria: prescription of intravenous fosfluconazole (Prodif ${ }^{\circ}$ intravenous solution $100 \mathrm{mg} / 1.25 \mathrm{~mL}$, Pfizer) for prophylaxis against fungal infection and neonates admitted to the neonatal intensive care unit. Patients were only recruited after written informed consent was obtained from the guardian(s). Following the protocol at our center, the fosfluconazole dose was set at $3 \mathrm{mg} / \mathrm{kg} / \mathrm{dose}$. The dosing intervals were once every $72 \mathrm{~h}$ until postnatal week 2 , once every $48 \mathrm{~h}$ from postnatal weeks 2 to 4 , and daily from postnatal weeks 4 to 6 , according to the standard dosing regimen for intravenous fluconazole [28]. The methodology developed was applied to a series of serum samples collected from ten subjects, including neonates receiving fosfluconazole for fungal infection prophylaxis. Serum samples were collected from an arterial line if available. Alternatively, heel-stick blood samples were used. No intervention was done during sampling, and only the samples left over from biochemical examinations were scavenged. The serum samples were collected and stored at $-80^{\circ} \mathrm{C}$ for a maximum period of 3 months until processing.

\section{Results}

Fluconazole detection

Figure 1 shows chromatograms of a blank serum sample (a) and a serum sample spiked with fluconazole and IS at a concentration of $2.0 \mu \mathrm{g} / \mathrm{mL}$ (b and c). The retention time was approximately $3.2 \mathrm{~min}$ for both fluconazole and IS. The total run time for each sample was $5.0 \mathrm{~min}$.

\section{Linearity, precision and accuracy}

Six-point calibration curve was found to be linear over the concentration range of $0.01-100 \mu \mathrm{g} / \mathrm{mL}$. After comparing the two weighting models $\left(1 / \mathrm{x}\right.$ and $\left.1 / \mathrm{x}^{2}\right)$, a regression equation with a weighting factor of $1 / \mathrm{x}^{2}$ of the drug to the IS concentration was found to produce the best fit for the concentration-detector response relationship for both the analytes in serum samples. Mean equation of calibration curve was $y=8.457 x+0.0006$ (Fig. 2), and the mean correlation coefficient of the weighted calibration curves generated during the validation was $\geq 0.99$. Intra and interday accuracy $(-7.7$ to $7.4 \%)$ and precision (0.3 to $6.0 \%$ ) were below $15 \%$ (Table 2). The estimated LOD by using the residual of standard deviation of regression and the slope of calibration curve was $0.0019 \mu \mathrm{g} / \mathrm{mL}$ while the LLOQ was $0.0031 \mu \mathrm{g} / \mathrm{mL}$.

\section{Recovery}

Higher precipitation recovery $(98.4 \pm 1.9 \%)$ was observed after sample preparation than in freshly prepared fluconazole in serum, suggesting that high extraction efficiency ensured fluconazole stability. Specificity testing was performed with blank serum samples from neonates prepared in the same way as the study samples. The endogenous components in the serum samples did not interfere with the compounds of interest.

\section{Matrix and carry-over effects}

The average matrix effects in all the six batches of serum for fluconazole calculated as the response of the post spiked sample/response of neat sample at each two concentration was 0.90 and 0.88 , respectively, which

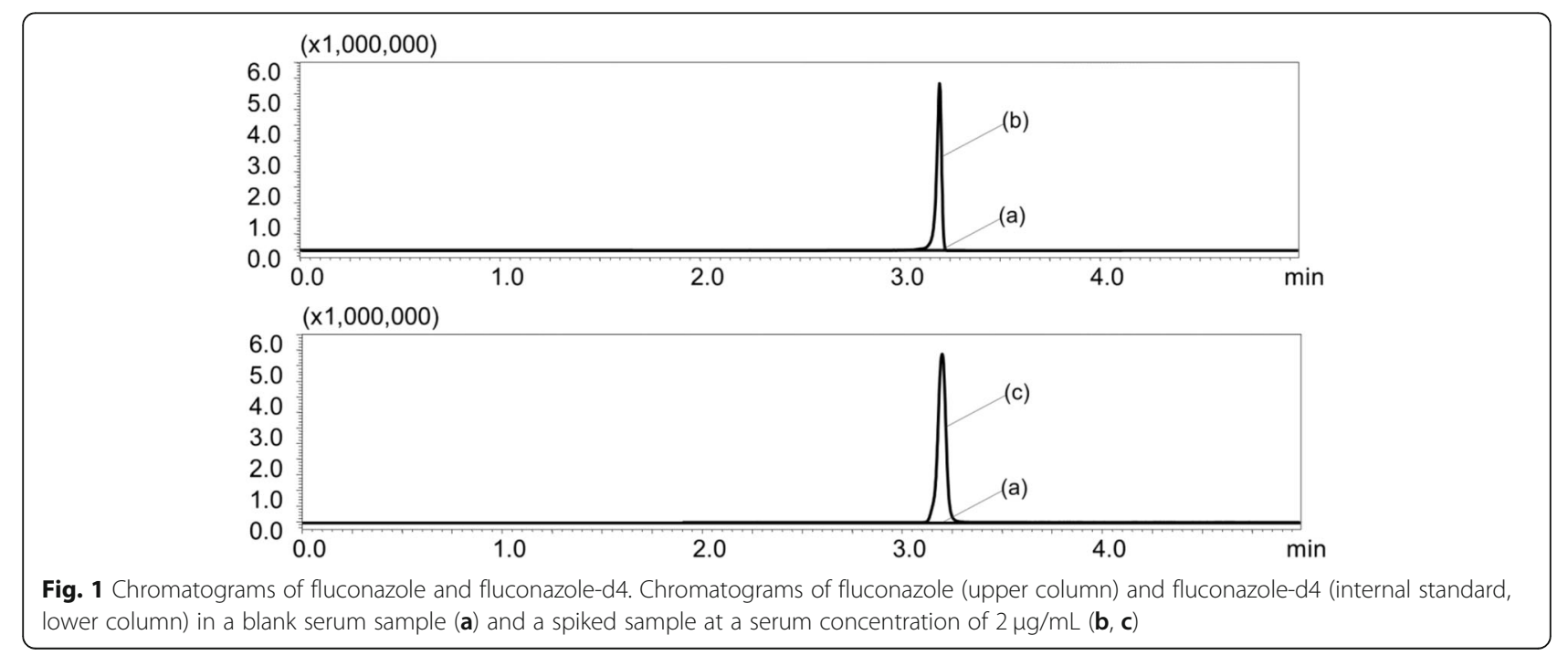




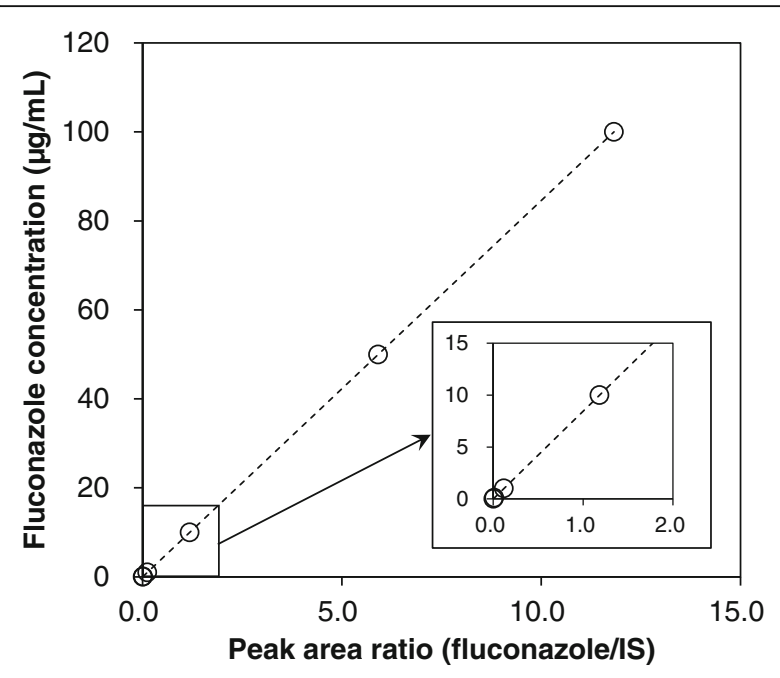

Fig. 2 Mean calibration curve for the LC-MS/MS analysis of fluconazole. The horizontal axis indicated the ratio of fluconazole to the internal standard (IS, fluconazole-d4) peak area. The vertical axis indicated the corresponding fluconazole concentrations. The dotted lines indicated the regression lines

indicated negligible significant suppression or enhancement. The variability of matrix effect at each level, as measured by the coefficient of variation, reached $\leq 15 \%$, thus explaining the reproducible results. The carry-over effect was tested by alternately injecting the highest QC sample and blank samples, and no carry-over was detected.

\section{Stability}

Fluconazole samples were stable during sample preparation and storage. The percentage (mean, relative standard deviation) of remaining fluconazole in the QC samples stored at $-20^{\circ} \mathrm{C}$ and $-80^{\circ} \mathrm{C}$ for 4 months and that of the freshly prepared samples was $97.7 \pm 2.0 \%$ and

Table $\mathbf{2}$ Intraday and interday assay precision and accuracy for fluconazole in serum samples

\begin{tabular}{llll}
\hline Conditions & Concentration $(\mu \mathrm{g} / \mathrm{mL})$ & Accuracy $(\%)$ & Precision $(\%)$ \\
\hline Intraday & 0.01 & -4.6 & 3.1 \\
& 0.1 & 4.7 & 4.6 \\
& 1.0 & -0.4 & 2.1 \\
& 10.0 & 7.4 & 3.4 \\
& 50.0 & 5.0 & 6.0 \\
& 100.0 & -7.7 & 5.8 \\
Interday & 0.01 & -4.4 & 4.3 \\
& 0.1 & 0.8 & 2.7 \\
& 1.0 & 3.0 & 0.3 \\
& 10.0 & 3.2 & 2.5 \\
& 50.0 & -2.5 & 2.5 \\
& 100.0 & -0.3 & 5.4 \\
\hline
\end{tabular}

$98.1 \pm 1.9 \%$, respectively. In all the QC samples, more than $98.0 \%$ of the fluconazole remained after sample treatment at $10^{\circ} \mathrm{C}$ for $48 \mathrm{~h}$, indicating that fluconazole was stable for over $48 \mathrm{~h}$ in the auto-sampler. The lower percentage of fluconazole remaining in the serum samples stored at room temperature $(92.3 \pm 3.9 \%)$, indicated that the corrected serum samples required storage at $20^{\circ} \mathrm{C}$ or $-80^{\circ} \mathrm{C}$. In freeze and thaw tests, repeated freeze-thaw cycles at six cycles were found to be within $\pm 15 \%$ of the predicted concentrations for fluconazole at each five QC levels.

\section{Application to pharmacokinetic studies}

The method validated in this study was applied to 234 serum samples taken from ten neonates who received fosfluconazole for antifungal prophylaxis. The calibration curve with six data points covering a concentration range of 0.01 to $100 \mu \mathrm{g} / \mathrm{mL}$ was used to determination of fluconazole concentration in serum samples. Summary statistics of the patient background, fosfluconazole dosage, and the fluconazole serum concentration after intravenous administration are presented in Table 3. Median time after dose (range) and median serum fluconazole concentrations (range) was $43.7(0.5-479.7)$ hours and $2.8(<0.01-26.8)$ $\mu \mathrm{g} / \mathrm{mL}$ for the sample from an arterial line, and $40.0(0.4-$ 467.4) hours and $3.3(<0.01-25.9)$ for the sample from a heel-stick, respectively. Additionally, the median (range) concentration up to $72 \mathrm{~h}$ after fosfluconazole administration was $2.9(0.02$ to $26.8 \mu \mathrm{g} / \mathrm{mL}) \mu \mathrm{g} / \mathrm{mL}$. These detected concentrations were within the range of the calibration curve, suggesting that the current method can be used successfully to measure fluconazole levels in neonates. In addition, the concentration-time data can be used to develop a population PK model that can be used in fosfluconazole dose optimization studies of preterm infants.

\section{Discussion}

The present study described the development of a selective and sensitive LC-MS/MS method for analyzing fluconazole in serum samples from preterm neonates receiving fosfluconazole. This method allowed a reduction in the serum sample volume to $10 \mu \mathrm{L}$, which is a realistic residual serum sample volume in real-world daily practice, and which enabled reliable quantification of fluconazole in blood samples obtained from preterm neonates. Acetonitrile precipitation is straightforward and does not require complicated liquid-liquid extraction or a costly solid-phase extraction column with a large amount of organic solvent. Our methods in this study have no novelty except for the initial amount of sample and sample pretreatment, and no specific techniques was used. However, developing the valid analytical methods contributes to improve the feasibility of pharmacokinetic analysis in preterm neonates. Although 
Table 3 Summary statistics of fluconazole serum concentrations after intravenous fosfluconazole administration

\begin{tabular}{|c|c|c|}
\hline Parameters & & Value \\
\hline Number of neonates (male/female) & & $10(6 / 4)$ \\
\hline Number of scavenged sampling points & & 234 \\
\hline \multirow[t]{2}{*}{ Sample volume } & $<25 \mu \mathrm{L}$ & 208 \\
\hline & $\geq 25 \mu \mathrm{L}$ & 26 \\
\hline Median gestational age (weeks, range) & & $28.5(23.3-33.4)$ \\
\hline Median weight ( $g$, range) & & $765(470-1000)$ \\
\hline Median height (cm, range) & & $33.0(28.0-38.0)$ \\
\hline Median fluconazole dose (mg/kg/dose, range) & & $3.1(2.7-3.7)$ \\
\hline \multirow[t]{2}{*}{ Sample from arterial lines $(n=178)$} & Median time after dose (hour, range) & $43.7(0.5-479.7)$ \\
\hline & Median concentration ( $\mu \mathrm{g} / \mathrm{mL}$, range) & $2.8(<0.01-26.8)$ \\
\hline \multirow[t]{2}{*}{ Sample from heel-sticks $(n=56)$} & Median time after dose (hour, range) & $40.0(0.4-467.4)$ \\
\hline & Median concentration ( $\mu \mathrm{g} / \mathrm{mL}$, range) & $3.3(<0.01-25.9)$ \\
\hline
\end{tabular}

the data about fluconazole levels after fosfluconazole treatment in preterm neonates is limited, the detected serum fluconazole concentration was comparable levels in premature neonates who were treated with 4.5 to 6 $\mathrm{mg} / \mathrm{kg}$ of fluconazole injection $[29,30]$. One of the limitations of this study was that the determination of fluconazole from plasma samples was not done. To increase feasibility by using scavenged samples for neonates, assay validation by using both serum and plasma samples is desirable. Additionally, verifying whether there is any difference in fluconazole concentration depending on the sampling site (sampling from an arterial line or a heel-stick blood sampling) is required.

\section{Conclusion}

LC-MS/MS detection method of quantifying fluconazole in neonates using a $10 \mu \mathrm{L}$ serum sample developed. This method may enable reliable quantification of fluconazole in neonatal blood samples for PK studies without the need for the larger sample quantities required by conventional methods.

\begin{abstract}
Abbreviations
VLBW: Very low birth weight; ELBW: Extremely low birth weight; NICU: Neonatal intensive care unit; PK: Pharmacokinetic; LC-MS/MS: Liquid chromatography-tandem mass spectrometry; IS: Internal standard; QC: Quality control; LOD: Limit of detection; LLOQ: Lower limit of quantification; UV: Ultraviolet; PP: Protein precipitation; LLE: Liquid-liquid extraction; SPE: Solid phase extraction; DBS: Dried blood spot
\end{abstract}

\section{Acknowledgments}

We thank Mr. James Robert Valera (National Center for Child Health and Development, Department of Education for Clinical Research, Japan) for his assistance with editing the manuscript.

\section{Authors' contributions}

J.S. and A.T. performed the research. J.S., A.T., Y.K., H.M., T.I., K.S., Y.I., and A.Y. designed the study. J.S. and A.T. analyzed the data. J.S., A.T., Y.K., H.M., T.I., K.S., Y.I., and A.Y. drafted the manuscript. The author(s) read and approved the final manuscript.

\section{Funding}

This work was supported by a domestic research and development grant from National Center for Child Health and Development (2020C-3) awarded to Ayano Tanzawa.

Availability of data and materials

Not applicable.

\section{Ethics approval and consent to participate}

This clinical study involving the collection of serum samples was approved by the ethical board of the National Center for Child Health and

Development.

\section{Consent for publication}

Written informed consent for the publication of any information that may lead to the identification of participants was obtained from the patients' guardians.

\section{Competing interests}

The authors declare that they have no competing interests.

\section{Author details}

${ }^{1}$ Department of Pharmacy, National Center for Child Health and Development, 157-8535, 2-10-1 Okura, Setagaya-ku, Tokyo, Japan. ${ }^{2}$ Division of Neonatology, Center for Maternal-Fetal, Neonatal and Reproductive Medicine, National Center for Child Health and Development, Tokyo, Japan. ${ }^{3}$ Division of Infectious Diseases, Department of Medical Subspecialties, National Center for Child Health and Development, Tokyo, Japan.

Received: 18 March 2020 Accepted: 27 May 2020

Published online: 01 July 2020

\section{References}

1. McCrossan BA, McHenry E, O'Neill F, Ong G, Sweet DG. Selective fluconazole prophylaxis in high-risk babies to reduce invasive fungal infection. Arch Dis Child Fetal Neonatal Ed. 2007:92:F454-8.

2. Kelly MS, Benjamin DK, Smith PB. The epidemiology and diagnosis of invasive candidiasis among premature infants. Clin Perinatol. 2015;42:105-17.

3. Swanson JR, Gurka MJ, Kaufman DA. Risk factors for invasive fungal infection in premature infants: enhancing a targeted prevention approach. J Pediatric Infect Dis Soc. 2014;3:49-56.

4. Benjamin DK Jr, Stoll BJ, Gantz MG, Walsh MC, Sánchez PJ, Das A, et al. Neonatal candidiasis: epidemiology, risk factors, and clinical judgment. Pediatrics. 2010;126:e865-73.

5. Benjamin DK Jr, Stoll BJ, Fanaroff AA, McDonald SA, Oh W, Higgins RD, et al. Neonatal candidiasis among extremely low birth weight infants: risk factors, mortality rates, and neurodevelopmental outcomes at 18 to 22 months. Pediatrics. 2006;117:84-92. 
6. Pappas PG, Kauffman CA, Andes DR, Clancy CJ, Marr KA, Ostrosky-Zeichner $L$, et al. Clinical practice guideline for the Management of Candidiasis: 2016 update by the Infectious Diseases Society of America. Clin Infect Dis. 2016; 62:e1-50.

7. Takahashi D, Nakamura T, Shigematsu R, Matsui M, Araki S, Kubo K, et al. Fosfluconazole for antifungal prophylaxis in very low birth weight infants. Int J Pediatr. 2009;2009:274768. https://doi.org/10.1155/2009/274768.

8. Ashbee HR, Barnes RA, Johnson EM, Richardson MD, Gorton R, Hope WW Therapeutic drug monitoring (TDM) of antifungal agents: guidelines from the British Society for Medical Mycology. J Antimicrob Chemother. 2014;69: 1162-76.

9. Couchman L, Buckner SL, Morgan PE, Ceesay MM, Pagliuca A, Flanagan RJ. An automated method for the simultaneous measurement of azole antifungal drugs in human plasma or serum using turbulent flow liquid chromatography-tandem mass spectrometry. Anal Bioanal Chem. 2012;404: 513-23.

10. Eerkes A, Shou WZ, Naidong W. Liquid/liquid extraction using 96-well plate format in conjunction with hydrophilic interaction liquid chromatographytandem mass spectrometry method for the analysis of fluconazole in human plasma. J Pharm Biomed Anal. 2003;31:917-28.

11. Müller C, Gehlen D, Blaich C, Prozeller D, Liss B, Streichert T, Wiesen MHJ. Reliable and easy-to-use liquid chromatography-tandem mass spectrometry method for simultaneous analysis of fluconazole, Isavuconazole, Itraconazole, Hydroxy-Itraconazole, Posaconazole, and Voriconazole in human plasma and serum. Ther Drug Monit. 2017:39:505-13.

12. Inagaki K, Takagi J, Lor E, Okamoto MP, Gill MA. Determination of fluconazole in human serum by solid-phase extraction and reversed-phase high-performance liquid chromatography. Ther Drug Monit. 1992;14:306-11.

13. Wattananat T, Akarawut W. Validated HPLC method for the determination of fluconazole in human plasma. Biomed Chromatogr. 2006;20:1-3.

14. Wu D, Wade KC, Paul DJ, Barrett JS. A rapid and sensitive LC-MS/MS method for determination of fluconazole in human plasma and its application in infants with Candida infections. Ther Drug Monit. 2009;31:703-9.

15. Chahbouni A, Wilhelm AJ, den Burger JC, Sinjewel A, Vos RM. Validated liquid chromatography-tandem mass spectroscopy method for the simultaneous quantification of four antimycotic agents in human serum Ther Drug Monit. 2010;32:453-7.

16. Decosterd LA, Rochat B, Pesse B, Mercier T, Tissot F, Widmer N, et al. Multiplex ultra-performance liquid chromatography-tandem mass spectrometry method for simultaneous quantification in human plasma of fluconazole, itraconazole, hydroxyitraconazole, posaconazole, voriconazole, voriconazole-N-oxide, anidulafungin, and caspofungin. Antimicrob Agents Chemother. 2010:54:5303-15.

17. Verdier MC, Bentué-Ferrer D, Tribut O, Bellissant E. Liquid chromatographytandem mass spectrometry method for simultaneous quantification of fou triazole antifungal agents in human plasma. Clin Chem Lab Med. 2010;48: $1515-22$.

18. Henry H, Sobhi HR, Scheibner O, Bromirski M, Nimkar SB, Rochat B. Comparison between a high-resolution single-stage Orbitrap and a triple quadrupole mass spectrometer for quantitative analyses of drugs. Rapid Commun Mass Spectrom. 2012;26:499-509.

19. Xiao Y, Xu YK, Pattengale P, O'Gorman M, Fu X. A rapid high-performance LC-MS/MS method for therapeutic drug monitoring of voriconazole, posaconazole, fluconazole, and itraconazole in human serum. J Appl Laboratory Med. 2017;1:626-36.

20. Skaggs CL, Ren GJ, Elgierari ETM, Sturmer LR, Shi RZ, Manicke NE, et al. Simultaneous quantitation of five triazole anti-fungal agents by paper spraymass spectrometry. Clin Chem Lab Med. 2020. https://doi.org/10.1515/cclm2019-0895.

21. Alffenaar JW, Wessels AM, van Hateren K, Greijdanus B, Kosterink JG, Uges DR. Method for therapeutic drug monitoring of azole antifungal drugs in human serum using LC/MS/MS. J Chromatogr B Analyt Technol Biomed Life Sci. 2010;878:39-44.

22. Gordien JB, Pigneux A, Vigouroux S, Tabrizi R, Accoceberry I, Bernadou JM, et al. Simultaneous determination of five systemic azoles in plasma by highperformance liquid chromatography with ultraviolet detection. J Pharm Biomed Anal. 2009;50:932-8.

23. Zhang S, Mada SR, Torch M, Goyal RK, Venkataramanan R. Development and validation of a high-performance liquid chromatographic assay for the determination of fluconazole in human whole blood using solid phase extraction. Ther Drug Monit. 2008;30:314-9.
24. Cociglio M, Brandissou S, Alric R, Bressolle F. High-performance liquid chromatographic determination of fluconazole in plasma. J Chromatogr B Biomed Appl. 1996;686:11-7.

25. Leroux S, Turner MA, Guellec CB, Hill H, van den Anker JN, Kearns GL, et al. Pharmacokinetic studies in neonates: the utility of an opportunistic sampling design. Clin Pharmacokinet. 2015;54:1273-85.

26. Food and Drug Administration Center for Drug Evaluation and Research (CDER). Bioanalytical Method Validation Guidance for Industry. 2018. https:// www.fda.gov/regulatory-information/search-fda-guidance-documents/ bioanalytical-method-validation-guidance-industry Accessed 29 May 2020.

27. International Organization for Standardization, ISO 11843-2:2000, Capability of detection -Part 2: Methodology in the linear calibration case. 2000. https://www.iso.org/obp/ui/\#iso:std:20186:en Accessed 9 Mar 2020.

28. Diflucan [package insert]. Tokyo, Japan: Pfizer Inc; 2017.

29. Turner K, Manzoni P, Benjamin DK, Cohen-Wolkowiez M, Smith PB, Laughon MM. Fluconazole pharmacokinetics and safety in premature infants. Curr Med Chem. 2012;19:4617-20.

30. Momper JD, Capparelli EV, Wade KC, Kantak A, Dhanireddy R, Cummings JJ, et al. Population pharmacokinetics of fluconazole in premature infants with birth weights less than 750 grams. Antimicrob Agents Chemother. 2016;60: 5539-45.

\section{Publisher's Note}

Springer Nature remains neutral with regard to jurisdictional claims in published maps and institutional affiliations.
Ready to submit your research? Choose BMC and benefit from:

- fast, convenient online submission

- thorough peer review by experienced researchers in your field

- rapid publication on acceptance

- support for research data, including large and complex data types

- gold Open Access which fosters wider collaboration and increased citations

- maximum visibility for your research: over $100 \mathrm{M}$ website views per year

At BMC, research is always in progress.

Learn more biomedcentral.com/submissions 